Х. М. Ніколайчук

\title{
СТРУКТУРА І СКЛАД МІКРОПОЛЯ «ДИТИНСТВО» (НА МАТЕРІАЛІ ПОЛЬСЬКОЇ ФРАЗЕОЛОГІї)
}

Ніколайчук Х. М. Структура і склад мікрополя «дитинство» (на матеріалі польської фразеологіі).

У статті здійснено аналіз польських темпоральних ФО в межах мікрополя «дитинство» 3 урахуванням трьох аспектів значення - сигніфікативного, денотативного і конотативного. 3'ясована роль корпусних досліджень в уточненні значення і місця ФО в мікрополі.

Ключові слова: мікрополе, сема, архісема, диференційна сема, фразеологічна одиниця, сигніфікативний, денотативний, конотативний аспекти значення.

Николайчук К. Н. Структура и состав микрополя «детство» (на материале польской фразеологии).

В статье осуществлен анализ польских темпоральных ФЕ в рамках микрополя «детство» с учетом трех аспектов значения - сигнификативного, денотативного и конотативного. Выяснена роль корпусных исследований в уточнении значения и места ФЕ в микрополе.

Ключевые слова: микрополе, сема, архисема, дифференциальная сема, фразеологическая единица, сигнификативний, денотативный, коннотативный аспекты значения.

Nikolaichuk K. N. The structure and composition of the microfield «childhood» (based on Polish phraseology)

The article is devoted to the analysis of Polish temporal idioms within micro field «childhood» with taking into account three aspects of meaning - significative, denotative and connotative. The role of corpus-based research has been found out to clarify the meanings of the idioms and its place in microfield.

Key words: microfield, sem, arhisem, differential sem, idiom, significative, denotative and connotative aspects of meaning. 
Людська екзистенція немислима без одного з базисних понять дійсності - категорії часу. Усе життя людського індивідууму протікає в системі координат темпоральності, однією 3 осей якої $\epsilon$ лінійне відображення вікових періодів: дитинство $\rightarrow$ молодість $\rightarrow$ середній вік $\rightarrow$ старість. Вікові характеристики у мовній системі вербалізовано головним чином за допомогою одиниць лексичного та фразеологічного фонду. Проблема експлікації віку мовними засобами неодноразово привертала увагу лінгвістів різних напрямів. Мовні засоби вираження віку $€$ об'єктом наукових зацікавлень О. Половинко (дисертаційне дослідження на матеріалі російської мови) [8], Ю. Орлової (дослідження на матеріалі української, російської та англійської мов) [5], Л. Поліщак (дослідження функціонально-семантичних та формально-граматичних особливостей чеських фразеологізмів на позначення вікових періодів в житті людини (дитинства, молодості, старості) [6; 7]. Особливості перекладу фразеологічної номінації віку на прикладі англійських фразеологічних одиниць (далі ФО) аналізує, зокрема, О. Тарнавська [9]. Основну увагу, однак, мовознавці здебільшого зосереджують на молодості та старості - періодах, безумовно, цікавих з огляду на свою «стереотипну обтяженість» та «аксіологічну забарвленість» (див. зокрема праці Ю. Коновалової (дисертація, присвячена семантикокогнітивному дослідженню специфіки вербалізації вікових концептів «Youth» («молодість») i «Old age» («старість») в англо-американській мовній картині світу, об'єктивованих фразеологізмами, пареміями i афоризмами) [4]; І. Блінової (дисертація, присвячена дослідженню концепту «старість» у російській та німецьких лінгвокультурах) [2]; певні стереотипи, пов'язані зі старістю та молодістю, виявлені на матеріалі українських прислів”їв, проаналізували В. Калько [3] та А. Ангелова [1]; мовні засоби вираження старості досліджували також польські лінгвісти, зокрема М. Вольни [17]).

Відсутність грунтовних комплексних досліджень фразеологічного вираження вікового періоду «дитинство» в польській мові, здійснених в межах відповідного мікрополя, зумовлює актуальність вибраної теми. Метою дослідження, отже, $є$ аналіз (з урахуванням тричленної смислової структури. Під семантичною структурою ФО розуміємо комбінацію сем усіх трьох смислових рівнів: сигніфікативного (є носієм поняттєвої інформації, загально відображає суть ФО), денотативного (конкретизація, уточнення значення) i конотативного (експресивний, емоційно-оціночний та функціонально-стилістичний компонент). семантики польських фразеологічних одиниць на позначення дитинства в межах відповідного темпорального мікрополя. Мета реалізовується 
через послідовне виконання таких завдань: 1) пошук і визначення корпусу польських ФО на позначення дитинства (системоцентричне вивчення); 2) виявлення контекстуальної реалізації темпоральних ФО (функціональний підхід); 3) систематизація та опис інформації про семантику аналізованих ФО на основі зіставлення даних системного та функціонального рівнів; 4) окреслення критеріїв локалізації ФО у ядерно-периферійних параметрах мікрополя «дитинство»; 5) конструювання фразеологічного мікрополя «дитинство». Селекцію фактичного матеріалу проводимо із джерел кодифікації ФО, а саме iз 10 фразеологічних та загальних словників (ISJP, MSF, SFJP, SFWP, SFWUTIA, USJP, WKS, WSF, WSFJP, WSFPWNZP) методом суцільної вибірки. Перелік умовних позначень див. наприкінці статті. До уваги взято лише ті ФО, у семантичній структурі яких сема «дитинство» має статус сигніфікативної (загалом 18 ФО (з усіма варіантами). Текстову реалізацію темпоральних ФО простежуємо в реєстрі контекстів Національного корпусу польської мови (далі НКПМ) та Інтернету.

Дослідження проводимо у напрямі від архісеми аналізованого

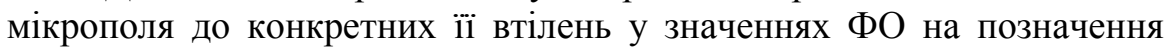
дитинства. Для з'ясування ядерно-периферійного наповнення мікрополя визначаємо низку критеріїв: 1) ядро конкретного мікрополя утворюють ті ФО, які безпосередньо виражають головну сему цього мікрополя - «дитинство»; 2) периферія мікрополя є 6-сегментною: 2.1) членування периферії мікрополя на сегменти залежить передусім від сигніфікативної структури значення його елементів - конкретних темпоральних ФО: а) ФО, які означають протяжність у часі, відліком якої $є$ нейтрально (без додаткових сем сигніфікативного характеру) означене дитинство, містяться на найближчій до ядра периферії; б) до периферії належать ФО, які в межах одного значення, крім темпоральної сигніфікатеми конкретного мікрополя (тобто архісеми певного мікрополя), мають ще й інші (диференційні) сигніфікатеми (темпоральні або нетемпоральні); в) розташування ФО на периферії має прямо пропорційну залежність від кількості сигніфікативних диференційних сем: чим більше конкретна ФО має додаткових сигніфікатем (тобто чим її сигніфікативне значення є розбудованішим), тим далі від ядра вона міститься; г) під час локалізації ФО беремо також до уваги семантичний характер диференційних сигніфікатем: на ближчих периферіях містяться ФО, у значенні яких вичленовуємо лише одну темпоральну сигніфікатему + іншу (нетемпоральну) сигніфікатему / інші (нетемпоральні) сигніфікатеми. Дальші периферійні сегменти утворюють ФО, у семантичній структурі яких 
на рівні сигніфікатеми виявляємо багатше семне наповнення темпорального змісту; г) ФО із сигніфікативним значенням «закінчення дитинства» розташовуються, відповідно, у крайньому периферійному сегменті після сегментів з ФО, які безпосередньо позначають цей період; д) ФО, у семантичній структурі яких темпоральна сигніфікатема («дитина») поряд з іншими семами того ж рівня $\epsilon$ експлікацією не реально біологічного віку людини, а особливостей ii світосприйняття, характеру тощо, що пов'язуються 3 дитинством, локалізовуємо в найвіддаленішому периферійному сегменті конкретного мікрополя; 2.2) локалізація темпоральних ФО в межах однієї периферії, тобто ФО, яким притаманна інтегральна сигніфікативна схема, зумовлюється денотативним характером семантичної структури аналізованих ФО: чим багатшим є денотативний набір сем певної ФО в порівнянні з іншою - конституентом тієї ж периферії, тим далі в межах однієї периферії вона міститься.

Ядро мікрополя «дитинство» утворюють ФО bańki nosem puszczać, nosić koszule w zębach, mieć gile pod nosem що означають «бути дитиною», «коли хтось був дитиною». У разі ФО bańki nosem puszczać, mieć gile pod nosem не виявлено жодного контексту, де б ці ФО актуалізовувалися в їхньому традиційному чи змодифікованому структурно-семантичному вигляді. Належність до ядра, однак, умотивована системним значенням цих ФО, зафіксованим у WSFJP, тобто «бути дитиною» (ФО bańki nosem puszczać має два сигніфікативних значення на системному рівні: крім темпорального, цій ФО властиве теж значення «(із зневаженням) пишатися, гордитися, безпідставно вважати себе кимось важливим» (WSFJP) (iз зазначенням легковажно-просторічної тональності для обох ФО).

Щоправда, немає однозначності в словниковому поясненні значення ФО nosić koszulę w zębach $(25(H)+10(I)=35(3 K)$ (тут і далі у дужках демонструємо частотність уживання певної ФО: вказуємо загальну кількість контекстів (3K), де було виявлено певну ФО в іi нормативному структурно-семантичному вигляді $(H)$ чи інноваційному вживанні (I). Фразеологічну інновацію, слідом за С. Бомбою, розуміємо як «будь-яке відхилення від фразеологічної норми» [11, с. 25]): згідно 3 ISJP, WSFPWNZP, SFWP, USJP ця ФО означає «бути малою дитиною», а WSFJP, крім цього сигніфікативного значення (+ конотатеми «легковажне», «пестливе»), подає ще й інше: (+ конотатема «з презирством») «бути молодою і психічно або соціально незрілою, несерйозною, невідповідальною людиною»: Nie przyjmuje do pracy chłopaków, co nosza koszulę $\boldsymbol{w}$ zębach, bo mi odstraszaja klientów. Jak 
przestanie nosić koszule w zębach, to może go zabiorę do kasyna". Отже, така ФО з відповідною сукупністю, як темпоральних («дитинство», «молодість»), так і нетемпоральних сем («психічна i соціальна незрілість», «несерйозність», «невідповідальність»), на системному рівні мала б міститися на периферії мікрополя «дитинство» і бути, відповідно, сполучною ланкою 3 мікрополем «молодість загалом». Однак урахування функціонального аспекту значення ФО nosić koszulę w zębach змінює іiі розташування: спостерігаємо транспозицію аналізованої ФО 3 периферійного сегмента мікрополя «дитинство» в його ядро.

Підставою для такого висновку слугують 25 контекстів, у яких ФО nosić koszule w zębach використано у значенні «бути малою дитиною»: Mimo że w latach 50. koszule w zębach nosit, w latach 60. byt szczylem, w 70. studiowat, a dopiero na progu lat 80. zacząt w polityce stawiać pierwsze kroki («Gazeta Wyborcza»). Тут і далі всі контексти з НКПМ та Інтернету подаємо в оригінальному написанні (без виправлень синтаксичних чи семантичних помилок). Не виявлено жодного контексту, у якому реалізовувалося б сигніфікативне значення «бути молодою і психічно або соціальнонезрілою, несерйозною, невідповідальною особою», що, своєю чергою, свідчить про ядрову належність (у межах мікрополя «дитинство») ФО nosić koszulę w zębach.

Перший периферійний сегмент формують ФО od kotyski $(359(H)+$ $9(I)=368(3 K)$, od kolebki $(132(H)+5(I)=137(3 K)$, od pieluch $(36(H)+1$ $(I)=37(3 K)$, інтегральним семантичним цілим яких є значення «від народження, від раннього дитинства». Ці ФО слугують для вираження динаміки (не статики) в часі, адже вони означають певний період, який може виходити поза межі одного темпорального мікрополя (щось, що відбувалося з дитинства, може відбуватися і зараз, і потім, і в молодості, i в старості тощо). Уважаємо, однак, локалізацію цих ФО на першій периферії мікрополя «дитинство» доцільною, оскільки стартовою точкою відліку все ж $є$ нейтрально (без факультативних сем сигніфікативного характеру) означене раннє дитинство.

Системне значення аналізованих ФО, згідно 3 емпіричними даними, еквівалентне функціональному на рівні усіх смислових аспектів: сигніфікативну значущість ФО od kotyski, od kolebki, od pieluch, а також їхнє конотативне значення - книжне маркування od kołyski, od kolebki та розмовний характер od pieluch- збережене у всіх проаналізованих контекстах. Наприклад: Moja matka od kołyski śpiewała mi ukraińskie dumki. Dzięki sassiadom Ukraińcom rodzice zdołali ujść z Wołynia z życiem. Myśle, że to jest wtaśnie tworzywo, z którego należy budować mosty nad dzielaca nasze narody historia («Gazeta Wyborcza»); Skąd Ty to wszystko 
wiesz? Beczke soli z Marzenka zjadtaś? Znasz ja od pieluch, że pozwalasz sobie na takie stwierdzenia? (Usenet- pl.soc.dzieci). Увиразненню сигніфікативного значення «ранне дитинство» сприяє також використання поряд з ФО od kolyski, od kolebki словосполучень, які сигналізують про кінець людського життя, таким чином автор немовби окреслює цілісно екзистенцію людини від іiі народження до смерті: od kolebki do grobu (24), od kolebki po grób (10), od kolebki do śmierci (4), od kolebki do trumny (2), od kolebki do mogity (1), od kolebki po starość (1), od kolebki aż do ostatniego tchnienia (1); od kołyski po grób (47), od kołyski do grobu (12), od kohyski po trumne (4), od kolyski do trumny (2), od kołyski aż po śmierć (2), od kotyski po emeryture (2), od kołyski do śmierci (1), od kołyski aż do końca życia (1), od kołyski aż po jesień życia (1); od kołyski do zakładu pogrzebowego (1), od kohyski aż do grobowej deski (1), od kołyski aż po kres naszego życia (1), od kołyski po starość (1). Наприклад: Człowiek przynależat do korporacji od kolebki do trumny, cech celebrowat jego chrzciny $i$ organizowat pochówek («Najstarszy zawód świata Historia prostytucji»); Wiadomo, że drewno, a tym samym wykonywane $z$ niego przedmioty towarzysza człowiekowi od kołyski, aż do grobowej deski («Czas Ostrzeszowski») та ін.

На другій периферії мікрополя «дитинство» міститься ФО тіес́ do szkoły pod górę (1 (3K без I) / górkę $(24(H)+34(I)=58(3 K)$, системне значення яких можна відобразити в конфігурації таких сем: «тяжке» (нетемпоральна сигніфікатема) + «дитинство» (темпоральна сигніфікатема) + «жартівливе» (конотатема). Синтез системних сигніфікатем («тяжке» (сигніфікатема 1) + «дитинство» (сигніфікатема 2) цієї ФО спостерігаємо також у 10 контекстах: Zdaje się, żeś kolego miat trudne dzieciństwo. Tata bili za siorbanie przy stole, czy do szkoły pod górke było? (Usenet - pl.rec.gory). Однак, численніше (23 контексти) в НКПМ та Інтернеті представлено інше значення ФО mieć do szkoly pod górę/ górkę (незафіксоване у словниках!) - «не вчитися, прогулювати заняття, зазвичай у школі». Наприклад: $C z y$ ty mialeś do szkoły pod górke $i$ opuszczateś lekcje j. polskiego, gdy omawiane byly zasady interpunkcji? Przecież tego bełkotu nie da się czytać, nawet jeśli twe argumenty sa stuszne (http://windows7.pl). Підтвердженням реалізації значення «не вчитися, прогулювати заняття, зазвичай у школі» $є$ також пояснення цієї ФО на форумi Określenie «mieć pod górkę» oznacza ogólnie trudności z czymś, jednak petnego stwierdzenia ,,mieć do szkoły pod górkę” IMHO używa się w znaczeniu, ze niechetnie sie korzystało $z$ edukacji, nie tyle $z$ przyczyn obiektywnych, co z wtasnego nastawienia (http://forum.gazeta.pl). Про експансивний характер незафіксованого у словниках значення («не 
вчитися, прогулювати заняття, зазвичай у школі») цієї ФО свідчать також дані 3 Інтернет-словників: антонімами до ФО mieć do szkoty pod górkę, наприклад, є дієслова douczać się, ksztatcić się, uczyć się (http://antonimy.net); як антонім (поряд 3 unikać nauki, wagarować, opuszczać lekcje/ zajęcia; obijać się, nie tęsknić za szkołal wiedza, zapominać, wychodzić z wprawy) до дієслова исzyć się подає ФО mieć do szkoty pod górkę інший Інтернет-словник (http://leksykony.interia.pl). Удвічі вища фреквентність нового значення ФО mieć do szkoty pod górę / górkę свідчить, очевидно, про те, що ця ФО виражає не стільки темпоральність, скільки негативні процеси, пов'язані зі школою i навчальним процесом. Однак, вважаємо, що ця ФО в кожному зі своїх значень (системному «важке дитинство» i новому (поки що лише функціональному значенні) «не вчитися, прогулювати заняття, зазвичай у школі») займає конкретне місце, 3 одного боку, у мікрополі «дитинство» (2 периферія), 3 іншого, належить до загального фразеосемантичного поля «школа».

ФО stary malutki $(28(H)+14(I)=42(3 K) /$ maleńki (44 (3K без $I)$, stara malutka (59 (3K без I) містяться на третій периферії мікрополя «дитинство». Ці ФО, беручи до уваги як системне, так і функціональне значення, мають доволі розбудовану семантичну структуру: «дитинство (темпоральна) сигніфікатема 1) + рання молодість (темпоральна) сигніфікатема 2)+ диференційна сигніфікатема статі (3) + надто серйозна поведінка, як на свій вік (сигніфіктема 4) + стиль, невідповідний до віку (одяг, макіяж, зачіска тощо), притаманний старшим (сигніфікатема 5)». На системному рівні виявляємо деякі розбіжності в дефініюванні цих ФО. Так, згідно 3 WSFPWNZP, ISJP, USJP ФО stary malutki / stara malutka мають, відповідно, значення «про хлопця, дівчинку, які поводяться надто серйозно, як на свій вік», а згідно 3 WSFJP stary maleńki / malutki (з презирством) - це також «дитина, яку одягають, як дорослого». Незважаючи на домінантну фіксацію у словниках першого значення, у прикладах мовленнєвого функціонування ФО stary malutki/ maleńki, stara malutka в НКПМ та Інтернеті частіше відображено саме інше значення - «одягнений, як дорослий» + нову сигніфікатему «яка має надто сильний макіяж, зачіску, яку зазвичай роблять дорослим дівчатам, жінкам». Усього виявлено 60 контекстів, де під ФО stary malutki/maleńki, stara malutka автор мав на увазі дитину, стиль (одяг, макіяж, зачіска) якої був схожим до стилю дорослої людини: Przypuszczalnie petne żenady byty to widowiska, ja starymalutki, dziecko-orator, kapłan-małolat musiałem być całkiem jak pokazujace się czasem $w$ telewizji $i$ zrobione na gwiazdy mate dziewczynki, które $\underline{w}$ 
estradowych kreacjach, wydekoltowanych sukniach, ostrych makijażach $i$ brawurowych fryzurach wygladaja jak pensjonariuszki ekskluzywnego burdelu dla zamożnych pedofilów («Polityka»). Функціональне обгрунтування наявності в семантичній структурі ФО stary malutki/ maleńki, stara malutka сигніфікативної семи «надто серйозна поведінка, як на свій вік» засвідчене в 47 контекстах: «Stara-malutka» mówi o Agatce pedagog szkolny Barbara Moskwa, bo dziewczynka próbuje naśladować świat dorostych («Życie Warszawy»).

У 14 контекстах, однак, у межах аналізованих ФО відбувається суттєва зміна у вікових рамках суб'єкта, а саме зміщення семантичного акценту 3 періоду дитинства на період ранньої молодості, що є ще одним свідченням периферійності цих ФО. Простежуємо поєднання сигніфікативних сем (радше рання) «молодість» і «стиль (одяг, макіяж, зачіска), невідповідний до віку, притаманний старшим»: I nagle odkrywam podstuchujacego: z siedzenia po drugiej stronie przejścia wpatruje się we mnie elegancki szesnastolatek, stary malutki, ubrany jak z zachodniego żurnala mód. Marynareczka, krawacik, beżowy płaszczyk («Linia nocna»). Неточності у словникових дефініціях, а також мовленнєві інновації, зафіксовані в НКПМ та Інтернеті, свідчать про модифікацію значення цієї ФО, пї збагачення новими сигніфікативними семами, зокрема й темпоральною.

Структурними елементами четвертого периферійного сегмента мікрополя «дитинство» є ФО ktoś jeszcze nie odróst od ziemi $(38(H)+2$ $(I)=40(3 K)$, ktoś ledwie $(11(H)+8(I)=19(3 K) /$ ledwo $(23(H)+8(I)=31$ (3K) odróst od ziemi. Згідно з WSFPWNZP та USJP ФO ktoś jeszcze nie odróst od ziemi має значення «про когось, хто ще не перестав бути дитиною, хто ще не є дорослим», WSFJP фіксує варіанти цієї ФО (ktoś ledwie / ledwo odróst od ziemi) і подає ширшу дефініцію, збагачуючи їх сигніфікативну структуру ще однією семою- «незрілий», а в ISJP знаходимо визначення: «говоримо зверхньо про когось, що він јеszcze nie odróst od ziemi, якщо він є ще дуже молодий (підкреслення наше Х.Н.)». На основі контекстних досліджень можна стверджувати про збільшення обсягу сигніфікативного компонента значеннєвої структури ФО ktoś jeszcze nie odróst od ziemi, ktoś ledwie / ledwo odróst od ziemi, адже у функціонуванні реалізовано 3 темпоральні сигніфікатеми: сигніфікатему «дитина» (11 контекстів: 4 - ktoś jeszcze nie odróst od ziemi, 6- ktoś ledwo odróst od ziemi, 1-ktoś ledwie odróst od ziemi), сигніфікатему «дуже молодий» (10 контекстів: 4 - ktoś jeszcze nie odróst od ziemi, 4-ktoś ledwo odróst od ziemi, 2-ktoś ledwie odróst od ziemi), сигніфікатему «молодий» (4 контексти: 3 - ktoś jeszcze nie odróst od ziemi, 
1 - ktoś ledwo odróst od ziemi). Наприклад: Miat być głęboki, wzruszający, chwytajacy za serce tekst. Miało być o pewnej dziewczynie, takim dzieciaku wtaściwie, co to jeszcze od ziemi nie odrosła, a tak straszne ciężary musi na swych barkach dźwigać (актуалізовується сигніфікатема «дитина»; http://otzycie.blox.pl); Pamiętasz swój pierwszy dzień na planie tego serialu? - No pewnie, byłam wtedy mała dziewczynkąm - 10-letnia, która ledwo co odrosta od ziemi (актуалізовується сигніфікатема «дуже молодий»; «Dziennik Polski»). Домінування сигніфікатеми «дитина» в НКПМ та Інтернеті зумовлює статус ФО ktoś jeszcze nie odróst od ziemi, ktoś ledwie I ledwo odróst od ziemi як периферійного елемента мікрополя «дитинство».

Системне конотативне забарвлення «із зневаженням», «зверхньо» (згідно з WSFJP, ISJP), спроектоване на функціональному рівні у 22 контекстах (9-ktoś jeszcze nie odróst od ziemi (3 них часові сигніфікатеми «дитина» і «молодий» актуалізовуються, відповідно, у 1 та 2 контекстах), 8 - ktoś ledwo odróst od ziemi (з них часові сигніфікатеми «дитина», «дуже молодий» і «молодий» актуалізовуються, відповідно, в 1, 3 та 1 контекстах), 5-ktoś ledwie odróst od ziemi (3 них часова сигніфікатема «дуже молодий» актуалізовується у 2 контекстах). Часто підвищення емоційності та експресивності висловлювання досягається появою у словесному оточенні аналізованих ФО лексем чітко окресленого (негативного) маркування: cipa, gówniara, gówniarz, kurdupel, nicpón szkaradny, smarkacz, smarkula, wypierdek moщs. Наприклад: Nauczycielka jest zdenerwowana-jak może przeprowadzić próbę bez Ani?! Wstrętna cipa, smarkula nie odrosła jeszcze od ziemi, a już zaczyna gwiazdorzyć (http://www.fantastyka.pl). Сучасний узус допускає також актуалізацію іншої конотатеми - «із захопленням». Нову конотатему неекспансивного характеру «із захопленням» зафіксовано у 8 контекстах: 3 - ktoś jeszcze nie odróst od ziemi (3 них часові сигніфікатеми «дитина» і «дуже молодий» актуалізовуються, відповідно, у 1 та 1 контекстах), 5-ktoś ledwo odróst od ziemi (3 них часові сигніфікатеми «дитина», i «дуже молодий» актуалізовуються, відповідно, у 3 та 1 контекстах). Конотатема «із захопленням» ускладнює смислову структуру ФО ktoś jeszcze nie odróst od ziemi, ktoś ledwo odróst od ziemi в контекстах, де йдеться про певні здобутки, таланти суб' єктів (позитивне денотативне оточення), окреслених аналізованими ФО: 13 lat, na prawde, koels jeszcze od ziemi nie odrosl a nagina jak perkusista Slayera....no moze to nie pasuje do koscielnego klimatu ale ma talent gosciu (http://baczaj.blox.pl); Tego jeszcze nie byto. Ledwo odrosta od ziemi, a już może pochwalić się MEGAsukcesem. I lepiej nie wchodzić w jej drogę. Bo... Niektórzy potrzebuja na to kilkudziesięciu lat. Jej wystarczyly zaledwie trzy. 
Do czego? Do zdobycia czarnego pasa w karata. Pochodzaca z Indii, Varsha Vinod, dokonała tej sztuki. Co $w$ tym dziwnego? Otóż to, że ma zaledwie piẹć wiosen na karku! (http://www.sportfan.pl).

На підставі системно-функціонального аналізу семантики ФО ktoś jeszcze nie odróst od ziemi, ktoś ledwie/ ledwo odróst od ziemi реконструйовуємо їх смислову структуру: «темпоральна сигніфікатема» («дитинство») + «темпоральна сигніфікатема» («рання молодість») + «темпоральна сигніфікатема» («молодість») + «нетемпоральна сигніфікатема» («незрілий»). Чотиричленна значеннєва організація аналізованих ФО зумовлює їх розташування у відповідному місці мікрополя «дитинство» - його четвертої периферії.

Конституентом четвертої периферії мікрополя «дитинство»є ФО cudowne dziecko $\left(721(H)+37(I)=758\left(3 K^{\prime}\right)\right.$. У семантичній структурі цієї ФО темпоральна сигніфікатема не є єдино основною, а виступає як супровідний компонент сигніфікатеми «талановитий». Семантичний потенціал ФО cudowne dziecko на рівні нормативного темпорального значення не обмежується лише семою «дитина», яка в лексикографічному описі WSF, USJP, WSFJP, SFJP зафіксована як сигніфікатема (пор.: «надзвичайно здібна, талановита дитина» (SFJP). Згідно 3 даними SFWP сема «дитина» $\epsilon$ факультативним елементом значення аналізованої ФО, тобто має денотативний характер: cudowne dziecko - «особа (яка зазвичай має мало років), що проявляє надзвичайні здібності у якійсь сфері, обдарована винятковим талантом». Контекстні дослідження дають змогу зробити ряд цікавих спостережень щодо вікового окреслення суб'єкта. Ситуативна вікова конкретизація суб'єкта номінації зафіксована у 119 контекстах. Темпоральне значення актуалізовується в них як константний семантичний елемент ФО cudowne dziecko, проте характеризується дифузністю, адже виступає комбінацією сем «дитинство» і «молодість» (як рання, так і пізня). Так, ФО cudowne dziecko автори контекстів окреслюють людину у віці: 2-7 років (38 контекстів), 8-10 років (9), 11-15 років (43), 16-20 років (22), 20-25 років (7). Наприклад: Grać na pianinie zacząt $w$ wieku 4 lat. Przez lwowskich krytyków muzycznych byt nazywany cudownym dzieckiem. Pierwszy koncert dat $w$ wieku 8 lat, natomiast $z$ towarzyszeniem orkiestry zagrat po raz pierwszy wieku 14 lat (http://wikipedia.pl); Bernoulli, sam matematyk $i$ astronom, pochodzacy $z$ wybitnie utalentowanej rodziny szwajcarskiej, uchodzit za cudowne dziecko, bowiem $w$ wieku dziewiętnastu lat został powołany na członka Akademii Nauk w Berlinie w klasie matematyki («Krasicki»).

Сигніфікатема «талановитий» як невід’ємний компонент значення 
ФО cudowne dziecko зумовлює їі статус як ФО позитивного спрямування, адже обдарованість певними здібностями у шкалі людських пріоритетів набуває, імовірно, меліоративної оцінки. У контекстах іноді простежуємо ситуативну адаптацію цієї сигніфікатеми: актуалізовуються денотатеми, які конкретизують сферу прояву таланту. Найчастіше cudowne dziecko - це дитина, обдарована у спорті (99 контекстів), музиці (92), акторському мистецтві (60), рідше в царині літератури (16): Niemal od poczatku zawodowej kariery-czyli od sześciu już lat wzbudza zainteresowanie. Wtedy jeszcze jako cudowne dziecko tenisa, dziś- «tylko» jako seksbomba («Gazeta Poznańska»); Kilka lat temu przypięto Ci tatkę cudownego dziecka rodzimej fantastyki. Na rynku literackim SF zaistniałeś brawurowo: jako szesnastolatek zachwyciteś specjalistów głębia metafizycznych refleksji $w$ «Złotej Galerze». Proza ta była tak dojrzała, że niektóre opiniotwórcze gremia zarzucity Ci wtedy plagiat («Dziennik Polski»).

Не завжди, щоправда, ФО cudowne dziecko реалізовується як сума семантичних компонентів «талановитий»+ «часові семи». Семантичну асиметрію системного i функціонального значення виявлено у 26 контекстах, у яких ФО cudowne dziecko властиве абсолютно нове сигніфікативне значення «щось виняткове, надзвичайне; якийсь дивовижний витвір». Наприклад: Mimo że formalnie przekroczyt właśnie czterdziestkę, przywykliśmy uznawać Internet za cudowne dziecko naszej cywilizacji. Zachtyśnięci jego możliwościami nie zauważyliśmy jednak, jak w tle rozwijała się cały czas jego mroczna strona («Polityka»); Niemożliwe stało się realne. F-22. Najnowsze cudowne dziecko amerykańskiego lotnictwa («Gazeta Wyborcza»). Беручи до уваги проаналізований фактичний матеріал, варто говорити, як нам видається, про полісемічний характер аналізованої ФО, адже, крім системного значення, виявлено продуктивну реалізацію іiі (некодифікованого) значення «щось виняткове, надзвичайне; якийсь дивовижний витвір». До того ж у мовленні спостерігаємо ускладнення набору елементарних одиниць системного значення ФО cudowne dziecko, що, як свідчать контекстні дослідження, $\epsilon$ субстратом аж трьох темпоральних сем: «дитинство»+ «рання молодість» + «молодість», супровідним елементом яких є нетемпоральна сигніфікатема «талановитий». Сигніфікативна структура ФО cudowne dziecko, згідно 3 результатами системно-функціонального аналізу, $\epsilon$ ідентичною семантичній організації на рівні сигніфікатем у разі ФО ktoś jeszcze nie odróst od ziemi, ktoś ledwie / ledwo odróst od ziemi. Дещо дальше (порівняно з ФО ktoś jeszcze nie odróst od ziemi, ktoś ledwie / ledwo odróst od ziemi) розташування ФО cudowne dziecko в межах тієї ж (четвертої) периферії зумовлене наявністю в іï значенні функціональних денотатем - 
конкретизація сфери прояву таланту (спорт, музика, мистецтво і т. ін.).

На ще дальшій (п’ятій) периферії мікрополя «дитинство» містяться ФО wyjść (10 (3K без $I) /$ wyzwolić się $(7(H)+1(I)=8(3 K) z$ powijaków. У словникових дефініціях WSFPWNZP та USJP ці ФО є полісемічними: ii значення «перестати бути дитиною», а також «вийти з початкової фази розвитку, розвинутися» мають автономний характер. ФО wyjść / wyzwolić się z powijaków окреслено як конституент п’ятої периферії мікрополя «дитинство», оскільки, відповідно до одного зі своїх значень, ця ФО сигналізує про закінчення дитинства. Зважаючи на наявність у семантичній структурі цих ФО семи фазовості («закінчення дитинства»), гадаємо, що доцільно локалізувати їх у периферійному сегменті, дальшому від ядрового орієнтира, ніж периферійні сегменти з ФО на позначення самого дитинства як біологічного віку людини.

Семантичний обсяг ФО wyjść / wyzwolić się z powijaków як конгломерату двох різних значень реалізовується у функціонуванні різною мірою. Найчастіше ці низькофреквентні ФО використовують у значенні «вийти з початкової фази розвитку, розвинутися»: wyjść $z$ powijaków, wyzwolić się z powijaków. Зафіксовано лише 1 контекст, у якому структурно модифікована ФО актуалізовується у значенні «перестати бути дитиною»: Świadomość ludzka zaczęła się we mnie budzić poczas najstraszniejszej $z$ wojen. Wtedy wynurzatem sie z powijaków wczesnego dzieciństwa. Byłem za maty, ̇̇eby uczestniczyć w konspiracji, lecz dostatecznie duży, żeby-przynajmniej od wieku 13 lat, jak to pamiętam - uciec z dookolnej grozy («Gazeta Wyborcza»). Варто також згадати, що в джерелах кодифікації, де описано ці ФО, ілюстративну інформацію подано лише до другого значення ФО, тобто до значення «вийти з початкової фази розвитку, розвинутися». Значення «перестати бути дитиною» у словникових статтях WSFPWNZP та USJP не підкріплено фактологічною конкретикою.

Структурним елементом шостої периферії мікрополя «дитинство» є ФО ktoś (jest) podszyty dzieckiem $(33(H)+14(I)=47(3 K)$. Локалізація цієї ФО в найвіддаленішій точці аналізованого мікрополя детермінована семантичною природою темпоральної семи: ідеться не про експлікацію реально біологічного віку людини, а про особливості характеру суб'єкта (пор.: ktoś (jest) podszyty dzieckiem - «хтось має риси дитини» (WSFPWNZP). Цій ФО властивий низький рівень актуалізації на функціональному рівні: нормативне значення ФО ktoś (jest) podszyty dzieckiem унаочнено лише у 33 контекстах (зі збереженням конотатеми «книжне»). Значення, кодифіковане у WSFPWNZP, наштовхує на певні 
міркування щодо аксіологічної оцінки характеру суб' єкта, окресленого ФО ktoś (jest) podszyty dzieckiem: можна припустити, що сигніфікатема «дитина», яка разом із сигніфікатемою «особливість характеру» творить єдине семантичне ціле, викликає певні негативні асоціації, адже якщо хтось у дорослому віці має риси, притаманні дитині, то, очевидно, проявляє ознаки інфантильності, несерйозності, ментальної незрілості тощо. Аналізована ФО, згідно з цією гіпотезою, набувала б негативного відтінку i слугувала б вербалізації дисбалансу між біологічним віком і ментальним розвитком людини в конкретних ситуаціях. Проаналізовані контексти спростовують вищеподане твердження: актуалізація сигніфікатеми «дитина» сприяє формуванню, навпаки, позитивних образів (мрійливий як дитина; життерадісний як дитина; безтурботний як дитина; допитливий як дитина тощо). Наприклад, сконденсованість позитивних асоціацій, які виникають навколо ФО ktoś (jest) podszyty dzieckiem, яскраво продемонстровано y контексті: Odnajduje swoja dziecinność m.in. $w$ muzyce - wtedy daje się ponieść chwili i czerpać radość garściami. Muzyka bardzo skutecznie naładowuje mi bateryjki i poprawia samopoczucie. Ciekawość $i$ zachwyt odnajduje na fasadach budynków za każdym razem jak spaceruje po toruńskiej starówce. Jest miliony rzeczy, które sprawiaja, że 'ciesze się jak dziecko’. Teraz Twoja kolej byś mógt cieszyć sie tym stanem: znajdź sposoby na to by wczuć się $w$ rytm swojego dziecięcego serca $i$ dołacz do grona dzieckiem podszytych (http://www.stevepavlinapopolsku.pl).

Отже, усі польські ФО, що експлікують дитинство, організовані за принципом ядерності / периферійності в межах відповідного мікрополя. Структурна самоорганізація мікрополя «дитинство» зумовлена семантичним обсягом (а саме: сигніфікативним та денотативним рівнями) їхніх конституентів - конкретних ФО на позначення цього вікового періоду. Розгортання польової структури відбувається внаслідок поетапної взаємодії аналізованих ФО і має такий вигляд: 1) ядро (архісема мікрополя реалізовується без додаткових нашарувань сигніфікативного рівня - «бути дитиною»): bańki nosem puszczać, mieć gile pod nosem, nosić koszulę w zębach; 2) периферійна зона (супровідними елементами архісеми («дитина») $є$ інші сигніфікатеми): 2.1) у першу периферію інтегровано ФО зі значенням «дитинство як стартова точка відліку подальшого життя людини»- ФО od kotyski, od kolebki, od pieluch; 2.2) у другу периферію об'єднано ФО 3 інтегральною сигніфікативною схемою «темпоральна сигніфікатема («дитина»)»+ «нетемпоральна сигніфікатема» - mieć do szkoły pod górę/ górkę; 2.3) у третю периферію об'єднано ФО 3 інтегральною сигніфікативною 
схемою «темпоральна сигніфікатема («дитинство»)»+ «темпоральна сигніфікатема («рання молодість»)» + «нетемпоральна сигніфікатема» + «нетемпоральна сигніфікатема» + «нетемпоральна сигніфікатема» - stary malutki / maleńki, stara malutka; 2.4) у четверту периферію об’єднано ФО 3 інтегральною сигніфікативною схемою «темпоральна сигніфікатема («дитинство»)»+ «темпоральна сигніфікатема («рання молодість»)»+ «темпоральна сигніфікатема («молодість»)»+ «нетемпоральна сигніфікатема». Цю периферію, своєю чергою, розчленовано на 2 частини: далі від ядра локалізовано ФО cudowne dziecko, у семантичній структурі якої виділено функціональні денотатеми, ближче - ФО ktoś jeszcze nie odróst od ziemi, ktoś ledwie/ ledwo odróst od ziemi, у значеннєвому обсязі яких вони відсутні; 2.5) у п’яту периферію об'єднано ФО 3 інтегральною сигніфікативною схемою «темпоральна сигніфікатема» + «сигніфікатема фазовості» («закінчення дитинства») wyjść / wyzwolić się z powijaków; 2.6) у шосту периферію інтегровано ФО ktoś (jest) podszyty dzieckiem, у значені якої темпоральна сигніфікатема «дитина» $\epsilon$ експлікацією не реально біологічного віку людини дитинства, а особливостей iї світосприйняття, характеру і т. ін., що притаманні дитині (+ «денотатеми»).

\section{Література}

1. Ангелова А. Рефлексія старості в українських приказках та прислів'ях / А. Ангелова // Науковий вісник Київського національного університету театру, кіно i телебачення імені І. К. Карпенка-Карого. - К., 2010. - Вип. 6. - С. 186-198.

2. Блинова И. Концепт «старость» в русской и немецкой лингвокультурах : автореф. дис. ... канд. філол. наук : 10.02.20 / Волгоградский государственный социально-педагогический университет - Волгоград, 2009.

3. Калько В. Концепти МОЛОДІСТЬ і СТАРІСТЬ в українській мові (на матеріалі паремій) / В. Калько // Лінгвістичні студії : зб. наук. праць. - Донецьк, 2012. - Вип. 24. C. $110-114$.

4. Коновалова Ю. Фразеологизмы, паремии и афоризмы как средство объективации возрастных концептов в англо-американской языковой картине мира : автореф. дисс. ... канд. филол. наук : 10.02.04. - Воронеж, 2012.

6. Орлова Ю. Мотивуючі ознаки концепту «вік людини» (на матеріалі української, російської та англійської мов) / Ю. Орлова // Актуальні проблеми іноземної філології : Лінгвістика та літературознавство. - Бердянськ, 2009. - Вип. 3. - С. 110-116.

7. Поліщак Л. Вираження часових відношень у чеській фразеології / Л. Поліщак // Вісник Львівського університету. Серія філологічна. - Львів, 2009. - Вип. 48. - С. 268-274.

8. Поліщак Л. Концепт «Час» у чеській фраземіці / Л. Поліщак // Проблеми слов'янознавства. - Львів, 2010. - Вип. 59. - С. 259-264.

9. Половинко О. Лінгвістичні та екстралінгвістичні фактори наповнення семантичних полів у сучасній російській літературній мові (семантичне поле вік) : автореф. дис. ... канд. філол. наук : 10.02.02. - Дніпропетровськ, 2006.

10. Тарнавська О. Фразеологічна номінація віку: перекладацький фактор 
О. Тарнавська // Вісник Сумського держ. Ун-ту. Серія : Філологічні науки. - Суми, 2006. - Вип. 2. - № 11. - С. 171-175.

11. Щур Г. Теории поля в лингвистике : [монографія] / Г. Щур. - М. : Наука, 1974. $-253 \mathrm{c}$.

12. Bąba S. Innowacje frazeologiczne współczesnej polszczyzny / S. Bąba. - Poznań : Wydawnictwo Naukowe Uniwersytetu im. Adama Mickiewicza, 1989. - $215 \mathrm{~s}$.

13. Buttler D. Koncepcja pola znaczeniowego / D. Buttler // Wybór literatury do słownictwa, frazeologii stylistyki. - Kraków, 1971. - Cz. 1. - S. 294-312.

14. Kania S. Pojęcie pola znaczeniowego // Zarys leksykologii i leksykografii polskiej / Pod red. S. Kania, J. Tokarskiego. - Warszawa : Wydawnictwa Szkolne i Pedagogiczne, 1984. - S. 166-168.

15. Pole semantyczne / S. Karolak // Encyklopedia językoznawstwa ogólnego / pod red. K. Polańskiego. - Wrocław - Warszawa - Kraków : Ossolineum, 1993. - S. 406-407.

16. Miodunka W. Podstawy leksykologii i leksykografii / W. Miodunka. - Warszawa : Państwowe Wydawnictwo Naukowe, 1989. - 268 s.

17. Tokarski R. Struktura pola znaczeniowego. Studium językoznawcze / R. Tokarski. Warszawa : Państwowe Wydawnictwo Naukowe, 1984.

18. Wolny M. Językowy obraz starości ludzi i zwierząt w polszczyźnie / M. Wolny // Język a kultura. - Wrocław, 2003. - T. 15. - S. 189-199.

\section{Перелік і скорочені назви лексикографічних джерел}

ISJP - Inny słownik języka polskiego / Pod red. M. Bańki : W 2 t. - Warszawa : Wydawnictwo Naukowe PWN, 2000.

MSF - Iglikowska T., Kurkowska H. Mały słownik frazeologiczny. Czas. Przestrzeń. Ilość. Liczba. Stopień. - Z. 1. - Warszawa : Wydawnictwo Uniwersytetu Warszawskiego, 1966. $-110 \mathrm{~s}$.

SFJP - Podlawska D. Słownik frazeologiczny języka polskiego / D. Podlawska, M. Świątek-Brzezińska. - Bielsko-Biała : Park, 2006. - 448 s.

SFWP - Bąba S. Słownik frazeologiczny współczesnej polszczyzny / Stanisław Bąba, Jarosław Liberek. - Warszawa : Wydawnictwo Naukowe PWN, 2001. - 1096 s.

SFWUTIA - Słownik frazeologiczny w układzie tematycznym i alfabetycznym / Pod red. A. Nowakowskiej. - Wrocław : Wydawnictwo Europa, 2003. - 472 s.

USJP - Uniwersalny słownik języka polskiego : W 4 t. / Pod red. S. Dubisza. - Warszawa : Wydawnictwo Naukowe PWN, 2006.

WKS - Mosiołek-Kłosińska K. W kilku słowach. Słownik frazeologiczny języka polskiego / Katarzyna Mosiołek-Kłosińska, Anna Ciesielska. - Warszawa : Wydawnictwo Szkolne PWN, 2001. - $540 \mathrm{~s}$.

WSF - Lebda R. Wielki słownik frazeologiczny / Renarda Lebda. - Kraków : Krakowskie Wydawnictwo Naukowe Spółka Jawna, 2009. - 720 s.

WSFJP - Müldner-Nieckowski P. Wielki słownik frazeologiczny języka polskiego / Piotr Müldner-Nieckowski. - Warszawa : Świat Książki, 2003. - 1088 s.

WSFPWNZP - Wielki słownik frazeologiczny PWN z przysłowiami/ Pod red. A. Kłosińskiej, E. Sobol, A. Stankiewicz. - Warszawa: Wydawnictwo Naukowe PWN, 2005. $-840 \mathrm{~s}$.

Стаття надійшла до редакції 14.11.2013 р. 